THE KURUME MEDICAL JOURNAL Vol. 14, No. 2, 1967.

\title{
EXPERIMENTAL STUDIES ON THE PERMEABILITY OF THE BLOOD VESSEL IN THE RABBIT AURICLE*
}

\author{
YOSHIO TAKESHIGE, M. D., F. I. C. A. \\ The First Department of Anatomy, Kurume University School of Medicine, \\ Kurume, Japan
}

(Received for publication July 14, 1967)

\begin{abstract}
Numerous studies have been reported on the permeability of the wall of blood vessels. Among these studies, the recent work which was reported by Majno and Palade (1961) was of particular interest. Physiologist, such as Huduck and Mc Master have experimentally demonstrated that some pigments which do not penetrate the wall of blood vessels under physiological condition are able to penetrate the wall of blood vessels when chemical or electrical stimulations are applied to animals.

This indicates that the permeability of the wall of blood vessels can be altered under experimental conditions.

Tracing the flow of substances which have moved out of blood vessels should be of interest. In the present experiment, morphological studies on the processes of movement of Indian Ink and HgS were made according to the method reported by Majno and Palade (1961).
\end{abstract}

\section{MATERIALS AND METHODS}

A certain amount of Indian Ink or HgS solution was injected into the external carotid artery 3 to 15 minutes after 0.05 cc 1.0 per cent histamine solution was injected intracutaneously into the depilated auricle of rabbits. Morphological studies of the animals which were killed 3 to 40 minutes after the test substance was applied to were made.

\section{RESULTS}

The observation with the electron and light microscope revealed that particles of test substance penetrated the wall of blood vessels. Furthermore, they were found to penetrate the wall of arteriole, and more often, the wall of venule, rather than to penetrate the capillary wall. These observations agreed with those of Majno and Palade (1961).

* Paper presented at the 6th Annual Meeting of the International College of Angiology and the 10th Annual Meeting of the American College of Angiology, Las Vegas, Nevada, U. S. A. June 17-20, 1964. 
It was also observed that some particles moved out through the intercellular space of endothelial cells and others moved out across endothelial cells.

Thus, the specimens obtained from an animal to which Indian Ink was applied 10 minutes after histamine injection and killed 10 minutes later showed obviously the movement of particles injected out of the blood vessels after penetrating the blood capillary wall. The particles were abundant inside and outside of the endothelial cell (Fig. 1), and the membrane vesiculation which is about to include particles can be seen in the plasma membrane of the endothelial cell. In the cytoplasm there are numerous vacuoles (Fig. 2).

In case of specimens taken from an animal which $\mathrm{HgS}$ solution was administered 10 minutes after the histamine injection and killed 15 minutes later, $\mathrm{HgS}$ particles were detected in the endothelial cell by way of the membrane vesiculation or pinopempsis (Moore and Luska, 1957) (Fig. 3). In addition, pictures in which HgS particles were pushed out of the blood vessels was not due these methods, but by passing through between two endothelial cells, though few in number, were observed.

When these specimens are observed with a light microscope, the particles of Indian Ink which penetrated the blood vessels even through the wall of the venule of a considerable size were observed (Fig. 4, 5). The particles which penetrated the wall of blood vessels seem to flow centripetally between the collagenous fibers of connective tissues located immediately outside of blood vessels (Fig. 6, 7, 8, 9). Finally, the particles reach the intercellular space of the auricular chondrocytes. This fact may indicate that the mechanism of supply of nourishment to chondrocytes (Fig. 10, 11, 12, 13). Furthermore, the presence of particles can be confirmed in the intercellular space of the hair-root (Fig. 14).

\section{DISCUSSION}

The result of our experiments on the permeability of the blood vessel were electron microscopically closely resemble the findings reported by Majno and Palade.

It was experimentally postulated by Mori (1963) that the permeability and the degree of permeation of blood vessels are varied with the nature of the penetrating fluid. Extreme care must be exercised in using reagents, such as histamine, serotonine, etc, and experiment preserving endothelial cells must be as much as possible under normal condition.

Our experiments revealed that particles of Indian Ink penetrated between the auricular chondrocytes, and it seems to be of much interest how nutritive substances are able to reach the tissues, such as chondrocytes, which cannot be nourished directly by blood flow.

Furthermore, particles of Indian Ink penetrating through the blood vessel were found to flow along the collagenous fibers as foreign matter and findings were confirmed in the wall of the rectum of rabbits. Namely, it was observed in vivo under a microscope that some particles of Indian Ink injected into the 
serosa of the rectum were in the located lymph vessels, going up to the wall of the stomach.

Others which did not enter the lymph vessels, flowed along the collagenous fibers located around the lymph and blood vessels and reached the capsule of the kidney and the wall of the ovarium. Of great interest in the finding that the substances penetrating the blood vessel are capable of flowing without passing through the blood or lymph vessel.

\section{SUMMARY}

1) The amount of particles of Indian Ink or $\mathrm{HgS}$ penetrating through blood vessels increases in the blood capillary, the arteriole and the venule in ascending order and the permeability of the blood capillary is almost nil.

2) Particles of Indian Ink within the lumen of blood vessel first enter the endothelium, then crossing the cytoplasm, leave the cell by pinopempsis, however, very few are found to penetrate between endothelial cells.

3) These particles moving out of the blood vessel flow centripetally along the perivascular collagenous fibers. However, unfortunately, the problem as to where they are taken into the blood or lymph vessel has not come to a definite conclusion.

4) Judging from the aforesaid findings it may be assumed that besides the flows of blood and lymph there exists a third flow of body fluid moving along the perivascular connective tissue.

\section{REFERENCES}

1) Rous, P, H. P. GILDING and F. SMITH : The gradient of vascular permeability. I. J. exp. M., Vol. 51, 807-830, 1930.

2 ) Starling, E. H. : On the absorption of fluid from the connective tissue spaces. J. Physiol., Vol. 19, 312-327, 1896 .

3 ) LANDIS, E. M. : Micro-injection studies of capillary permeability. II. Am. J. Physiol, Vol. 82, 217-238, 1929.

4) Kawano, K. : A new fact and problem concerning the permeability of venules, I. Acta. Path. jap., Vol. 1, 48-55, 1951.

5 ) Kawano, K. : A new fact and problem concerning the permeability of venules. II Acta. Path. jap., Vol. 1, 72-78, 1951.

6) Pfaff, W. and W. Herold: Versuche am Mesenterium des lebenden Kaninchens. In Grundlagen einer neuen Therapieforschung der Tuberculose. Leipzig : Georg Thieme, 1937.

7) Chambers, R. and B. W. ZWeifach : Intercellular cement and capillary permeability. Physiol. Rev., Vol. 27, 436-463, 1947.

8 ) Pappenheimer, J. R. : Passage of molecules through capillary walls. Physiol. Rev., Vol. 33, 387-423, 1953.

9) Palade, G. E. : Fine structure of blood capillaries. J. Appl. Physics, Vol. 24, 1424, 1953. 
10) Bennett, S., J. H. Luft and J. C. Hampton: Morphological classifications of vertebrate blood capillaries. Am. J. Physiol, Vol. 196, 381, 1959.

11) Yasuhiro, K. : Studies on the Leukocyte-Emigrating Factor (I). Acta. Path. jap, Vol. 1, No. 1, 7-13, 1951.

12) Moore, D. H. and H. RuSKa: The fine structure of capillaries and small arteries. J. Biophys. Biochem. Cytol, Vol. 3, 457-462, 1957.

13) Pawcett, D. W.: The microcirculation, I. Urbana: University Illinois Press, 1955.

14) BenNetT, S.: The concepts of membrane flow and membrane vesiculation as mechanisms for active transport and ion pumping. J. Biophys. Biochem, Cytol, Vol. 2, 99-103, 1956.

15) OHORI, R. : Morphological demonstration in electron micrographs of the passage of some electrolyte solutions between capillary endothelial cells. Nagoya Med. J, Vol. 9, 1963.

16) Palade, G. E.: Transport in quanta across the endothelium of blood capillaries. Anat. Rec, Vol. 136, 254, 1960.

17) Majno, G. and G. E. Palade : Studies on inflammation. I. The effect of histamine and serotonin on vascular permeability: An electron microscopic study. J. Bioph. Biochem. Cytol., Vol. 11, 571-598, 1961.

18) Majno, G. and G. E. Palade: Studies on inflammation. II. The site of action of histamine and serotonin along the vascular tree: A topographic study. J. Bioph. Biochem. Cytol, Vol. 11, 607-626, 1961.

19) Francis P. Chinard, Gilbert J. Vosburch and Theodore Enus : Transcapillary Exchange of Water and of Other Substances in Certain Organs of the Dog. American J. of Physiology, Vol. 183, 221-234, 1955.

20) Mori, K., Yamada, S., Ohori, R., Okada, H. and Suhara, A.: The spread of various subcutaneously injected dye fluids in connective tissue. Nagoya Med. J. Vol. 7, No. 3-4, 1961.

21) Mori, K., Yamada, S., Ohori, R., TAnaka, M. and Naito, T.: In vivo observation on the movement of tissue fluid in the connective tissue. Okajima's Fol. anat. jap, Bd. 39, Heft 4, 179-189, 1963.

22) Kinara, T. : Das extravaskuläre Saftbahnsystem. Okajima's Fol. anat. jap., Bd. 28, 601$621,1956$.

23) Mc Master, P. D. and R. J. Parsons: The movement of substances and the state of the fluid in the intradermal tissue. Annals N. Y. Acad. Sci., Vol. 52, Art. 7, 902-1003, 1950.

24) DAy, T. D. : The spread of fluids in connective tissue. J. Path. Bac, Vol. 60, 150-151, 1948.

25) KETY, S. S. : Measurement of regional circulation by the local clearance of redioactive sodium. Amer. Heart J., Vol. 38, 321-328, 1949.

26) Hyman, C., et al.: In dependence of capillary filtration and tissue clearance. Amer. J. Physiol, Vol. 168, 674-679, 1952.

27) Staubesand, J. : Cytopempsis. Organisation der Zelle. II. Sekretion und Exkretion. 163189, Springer-Verlag 1965.

28) Moore, D. H. and RuSKA, H. : The fine Structure of capillaries and small arteries. J. B. B. C., Vol. 3, 457, 1957. 


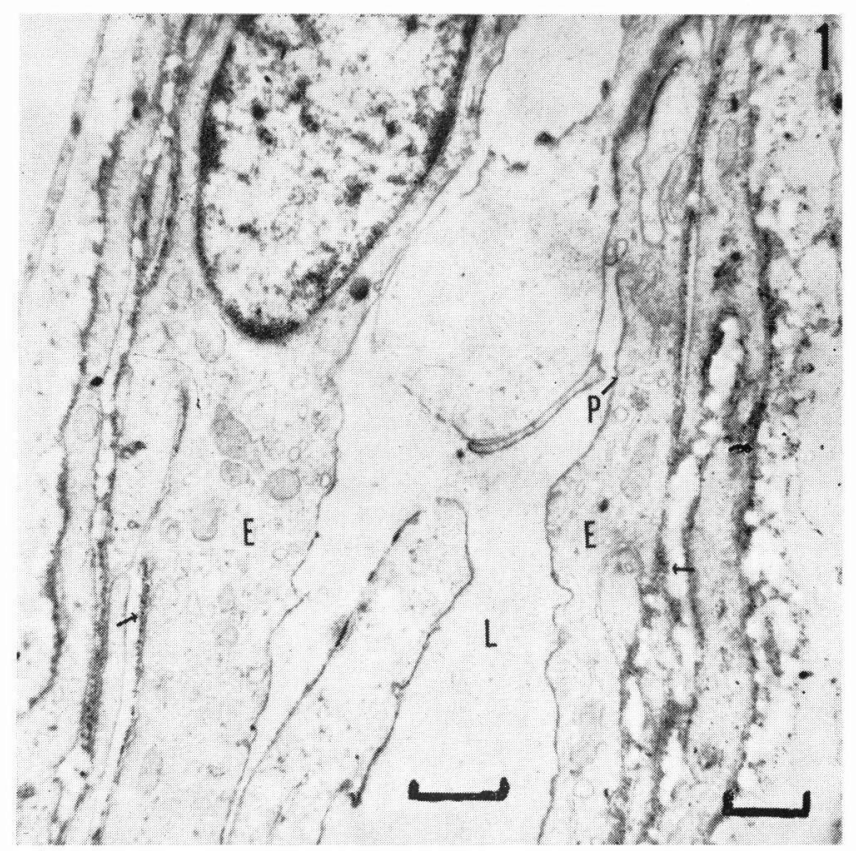

Fig. 1. Electron microscopic photograph. $\times 13,000$

$\mathrm{E}$ : Endothelial cell, L : Lumen of venule, $\mathrm{P}$ : Pinopempsis $\mathrm{N}$ : Nucleus, Arrow shows particles of Indian Ink.

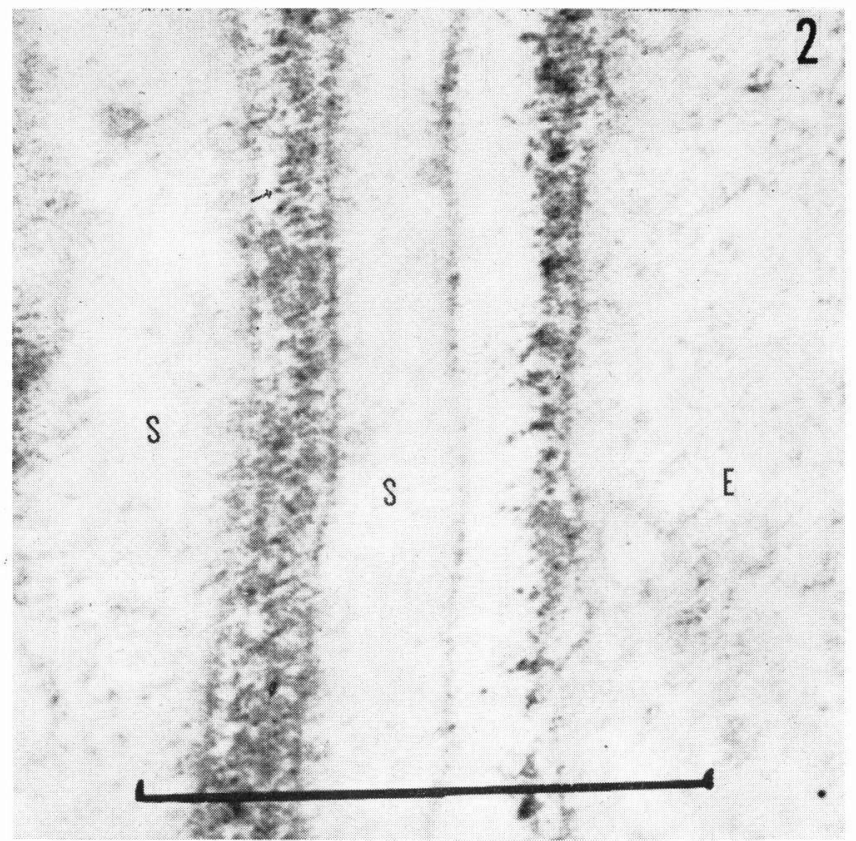

Fig. 2. Enlarged picture of a portion of Fig. 1. $\times 70,000$

E : Endothelial cell, $\mathrm{S}:$ Smooth muscle cell. 


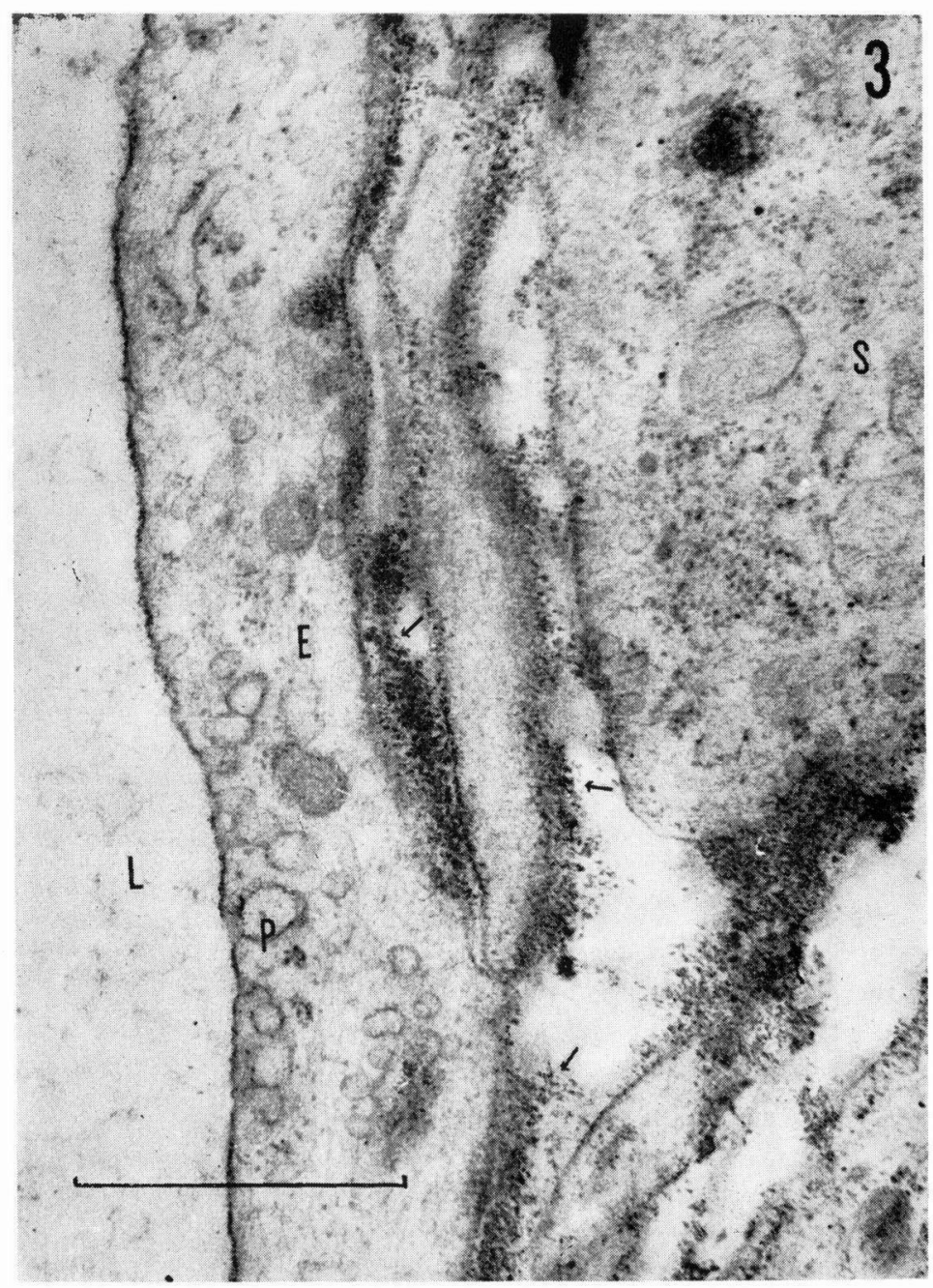

Fig. 3. Electron microscopic photograph. $\times 35,000$ E : Endothelial cell, L : Lumen of venule, $\mathrm{S}$ : Smooth muscle cell, P : Pinopempsis. 
Fig. 4. Longitudinal section of venule. $\times 3,500$ (H. E.)

$\mathrm{L}$ : Lumen of venule,

$\mathrm{W}:$ Wall of venule.

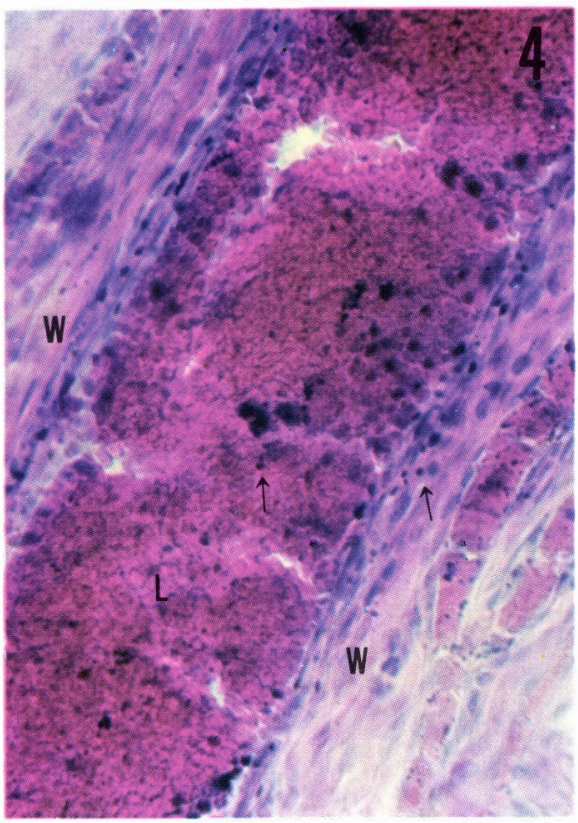

Fig. 6. Particles of Indian Ink (arrow) are seen in the collagenous

fiber (F). (Van Gieson) ×2, 500 .

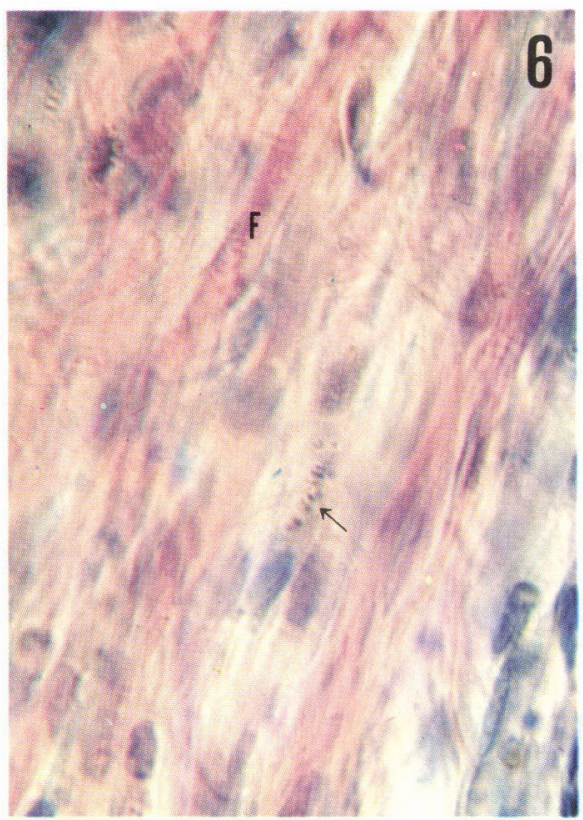

Fig. 5. Longitudinal section of venule. $\times 3,500$ (H. E. )

$\mathrm{L}:$ Lumen of venule,

W : Wall of venule.

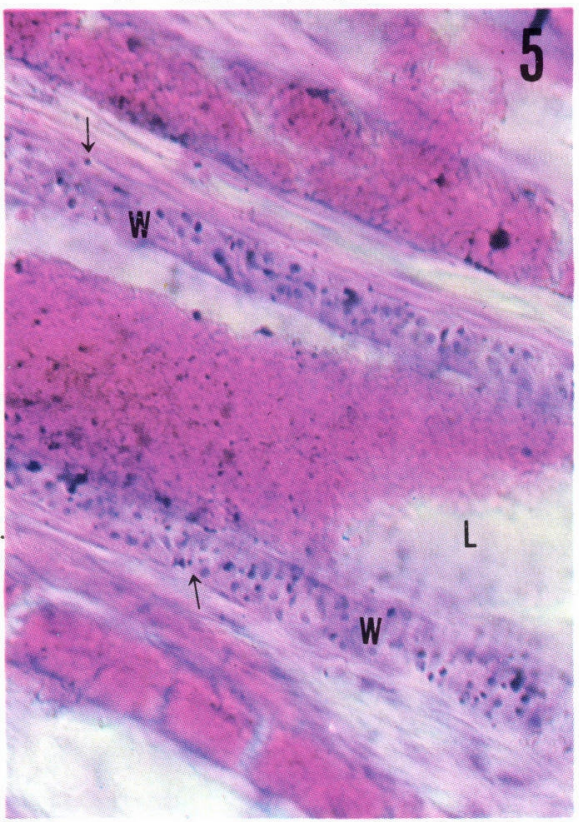

Fig. 7. Particles of Indian Ink (arrow) are seen in the collagenous fiber (F). C : Blood capillary. (Van Gieson) ×2, 500 .

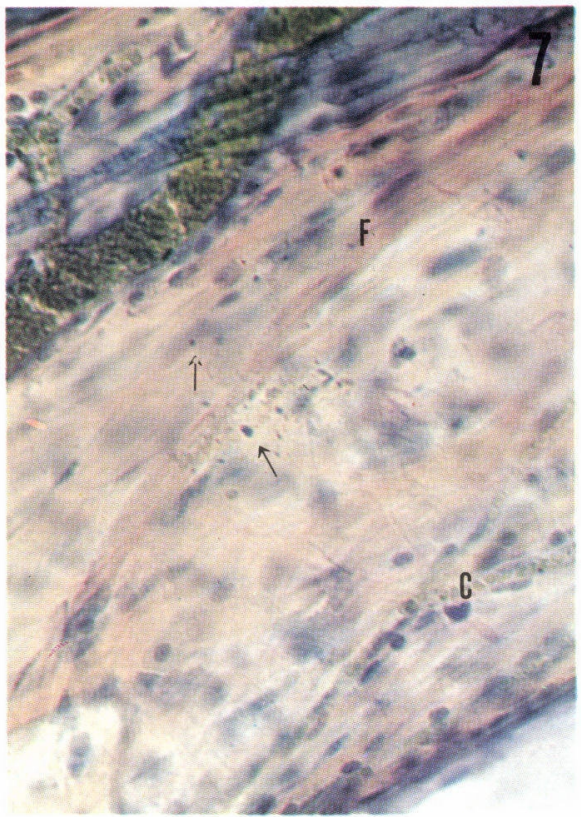


Fig. 8. Particles of Indian Ink (arrow) are seen in the collagenous fiber. (Van Gieson) $\times 2,500$. $\mathrm{C}:$ Blood capillary.

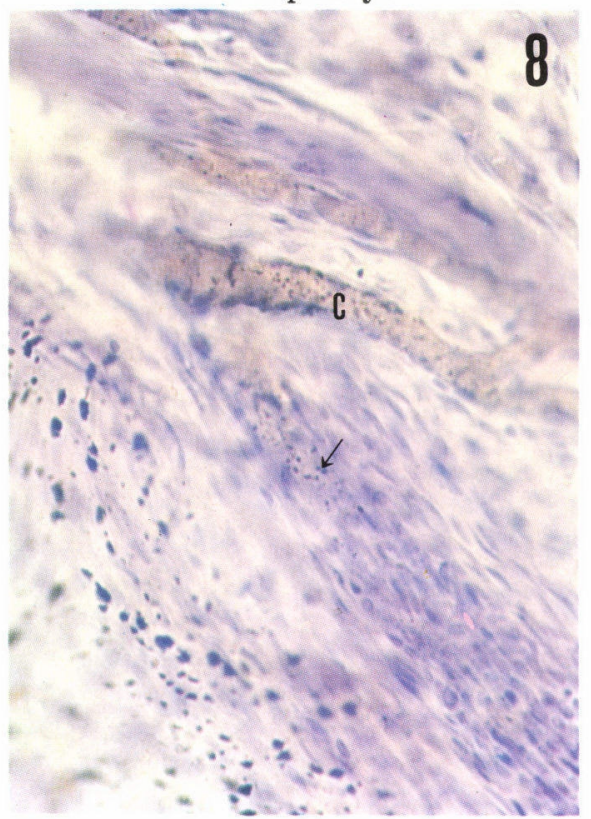

Fig. 10. Many particles of Indian Ink (arrow) are seen in the intercellular space of chondrocytes. x 800. (Van Gieson) $\mathrm{CH}$ : Chondrocyte.

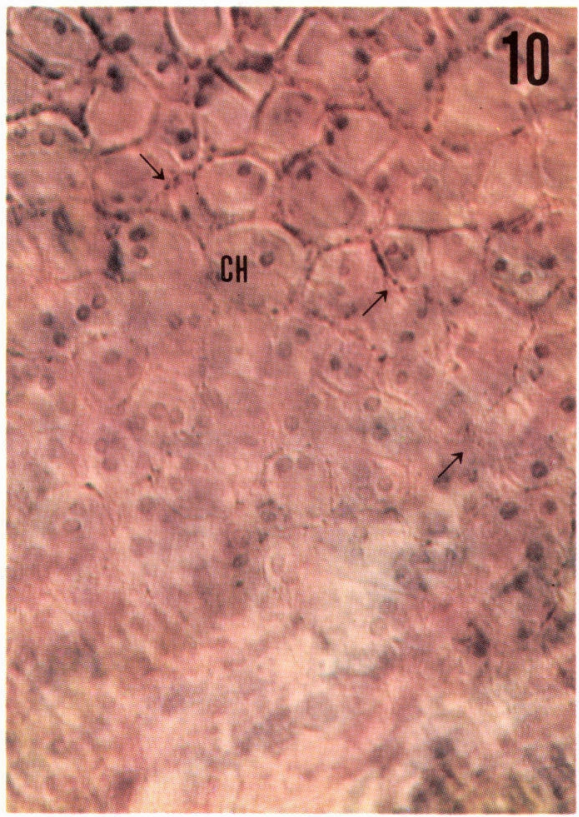

Fig. 9. Sketch of specimen of Fig. 8 . Particles of Indian Ink are conspicuous.

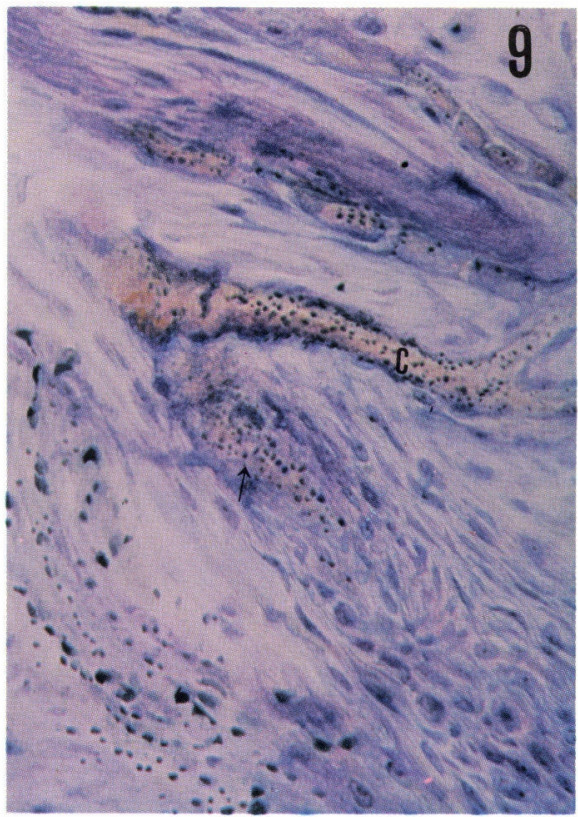

Fig. 11. Enlarged picture of a portion of Fig. 10. $\times 3,500$. (VanGieson) $\mathrm{CH}$ : Chondrocyte.

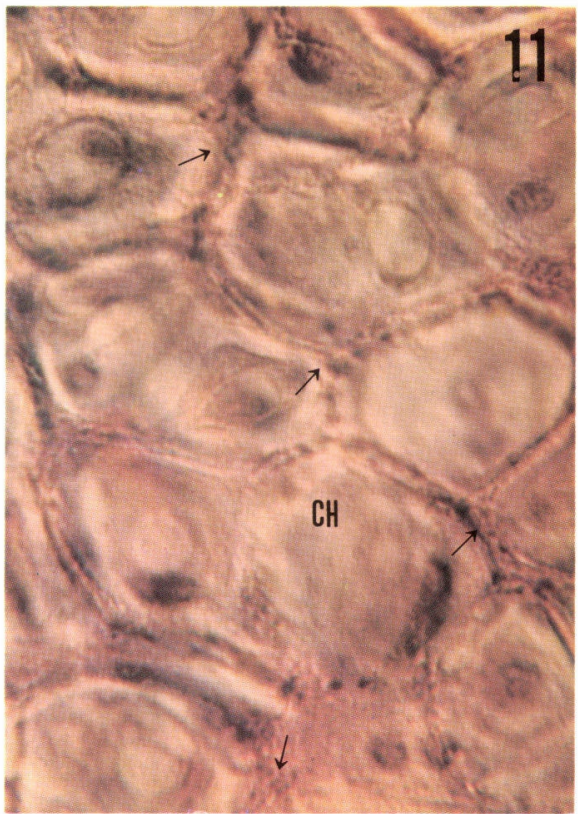


Fig. 12. Enlarged picture of a portion of Fig. 10. $\times 3,500$ (Van Gieson) $\mathrm{CH}$ : Chondrocyte. $\mathrm{F}$ : Collagenous fibers.

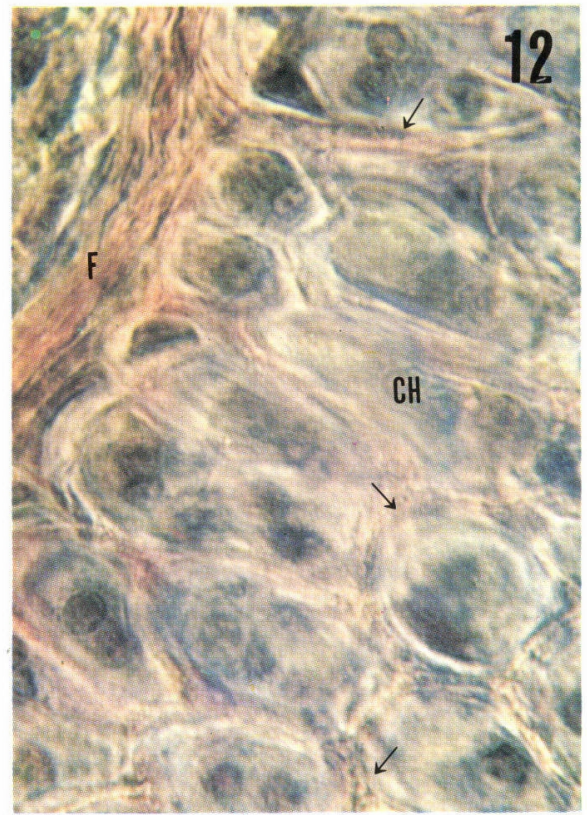

Fig. 13. Sketch of specimen of Fig. 12. Paricles of Indian Ink are conspicuous.

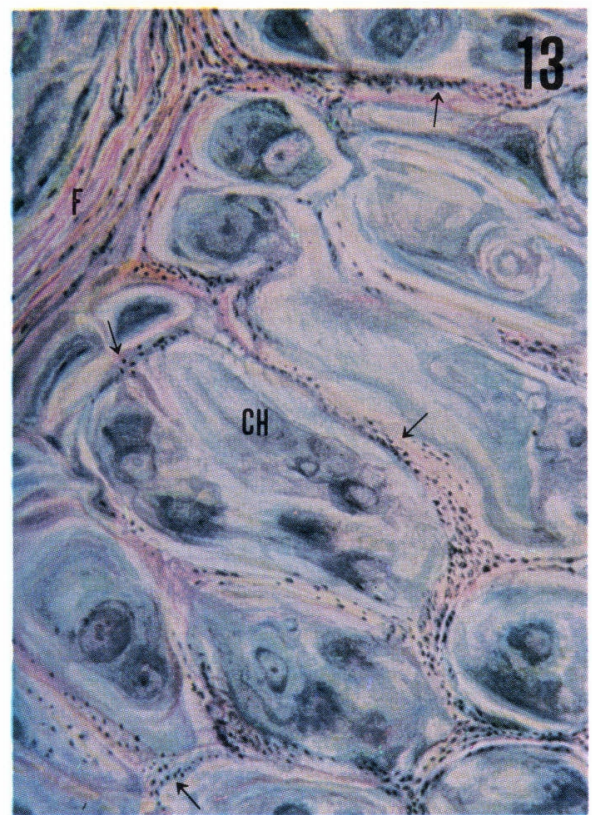

Fig. 14. Many particles of Indian Ink (arrow) are seen in the hairroot. $\times 800$ (H. E. ) $\mathrm{C}:$ Blood capillary.

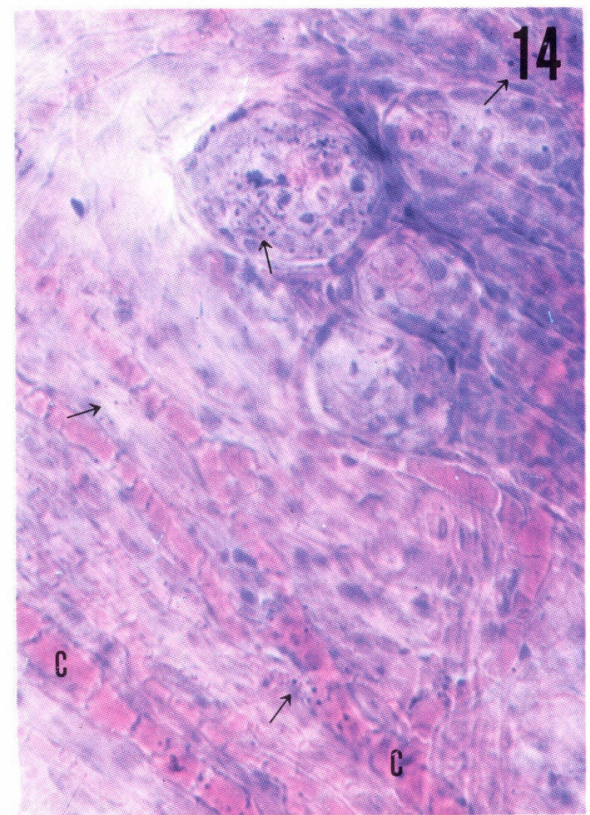

